Www.jmscr.igmpublication.org

Impact Factor (SJIF): 6.379

Index Copernicus Value: 79.54

ISSN (e)-2347-176x ISSN (p) 2455-0450

crossrefDOI: https://dx.doi.org/10.18535/jmscr/v6i10.156

Journal Of Medical Science And Clinical Research

IGM Publication

An Official Publication of IGM Publication

\title{
Comparison between Sutures and Staplers - Which is Better for Laparotomy Wound Closure
}

\author{
Authors \\ Dr N. Junior Sundresh ${ }^{{ }^{*}}$, Dr M. Devagi², Dr D.Gopikrishna ${ }^{3}$ \\ ${ }^{1}$ Associate Professor, Department of General Surgery, Rajah Muthiah Medical College, Chidambaram, \\ Tamilnadu \\ ${ }^{2}$ Post Graduate, Department of General Surgery, Rajah Muthiah Medical College, Chidambaram, Tamilnadu \\ ${ }^{3}$ Reader, General Medicine, Rajah Muthiah Medical College, Chidambaram, Tamilnadu
}

Corresponding Author

Dr M. Devagi

Post Graduate, Department of General Surgery, Rajah Muthiah Medical College, Chidambaram, Tamilnadu Email:DrDevagiSritharan@gmail.com

\begin{abstract}
Background: Wound closure biomaterials were of three types sutures, staplers/ ligating clips and tissue adhesives. The consensus of either suture or stapler is better for wound closure in case of laparotomy is yet to be arrived.

Materials and Methods: This was a non randomised controlled trial done among the patients admitted for laparotomy in tertiary care hospital. 50 patients were recruited into experimental group (wound closure with staples) and 50 recruited as controls (wound closure with sutures), after obtaining informed consent. After the surgery the investigator evaluated the study participants and recorded various variables like wound infection, wound dehiscence etc.

Results: The time for wound closure was significantly lesser in the staples group than the suture group. Wound infection was present in $36 \%$ of cases in the staples group and in $74 \%$ of cases in the suture group. Good cosmetic appearance was present in $82 \%$ of the staples group and $54 \%$ of the sutures group Discomfort in suture removal was present only in $6 \%$ of the cases when staples were used against $96 \%$ when sutures were used. $88 \%$ of the patients were satisfied in staples group against $38 \%$ in the control group. All the above mentioned variables were found to statistically significant.

Conclusion: Staples were superior to sutures with respect to time for closure of the wound, occurrence of lesser complications namely lesser wound infections, better cosmesis, less discomfort during suture removal. All the above led to a satisfied patient.
\end{abstract}

Keywords: Staples, sutures, wound bio-materials, laparotomy.

\section{Introduction}

The treatment and healing of wound is an art as old as humanity ${ }^{(1)}$. The principle aims of tissue repair of surgical skin incisions are rapid acquisition of strength and minimum tissue damage with minimum inflammation and a good scar $^{(2)}$. Many factors influence the above principle aim, but of particular importance are accurate coaptation of the dermal margins, eversion or inversion leads to suboptimal healing ${ }^{(3)}$. 
Every operation requires the use of bio -materials to close the wound for subsequent successful healing ${ }^{(4)}$.Wound closure biomaterials were of three types sutures, staplers/ ligating clips and tissue adhesives ${ }^{(5)}$. Suture threads are the most common means of wound closure, because they are readily available, easy to use, and efficient and because suture material provides the mechanical support necessary to sustain the closure $^{(3)}$. Surgical stapling was developed in 1908 by Hulti Humer in Australia. the original instrument was massive by today's standards weighing 7.5 pounds ${ }^{(2)}$. The development of mechanically satisfactory skin staplers appears to represent an important advance in rapid and effective means of closing long skin incisions. Staplers usually caused considerably lesser damage to wound defences when compared even with the least reactive non-absorbable suture material ${ }^{(6)}$.

The various factors which could determine what to choose between sutures and staples for skin closure included complication rate, patient satisfaction, cosmesis, operation time and pain during removal ${ }^{(7)}$. Studies comparing staples with sutures had been very minimal in southern India and the one comparing them in case of skin closure in abdominal surgeries is almost not found. This study was done mainly to compare staplers with sutures as a bio-material for skin closure in case of abdominal surgeries. Both the suture bio-materials will be compared against the following selected parameters like the ease and speed with which the skin closure is completed, the level of patient discomfort, the final cosmetic result and the complication rate.

\section{Materials and Methods}

This non-randomised controlled trial was carried out in the department of general surgery, Rajah Muthiah Medical College and Hospital, Annamalai University, Chidambaram between March 2017 to March 2018. The study was approved ethically by the institute's ethical committee. All the patients admitted in the department of general surgery for laparotomy were included into the study after getting informed consent. No blinding was done during the study as the patient would eventually come to know of the suture material used. No randomisation was done as the surgeon decided whether to go for sutures or staplers for skin closure.

After the surgical procedure the investigator evaluated the study participants. Then the investigator visited the study participants during the $3^{\text {rd }}, 7^{\text {th }}, 14^{\text {th }}$ and $30^{\text {th }}$ post-operative days and recorded the details regarding wound infection, wound dehiscence. The other variables recorded include cosmetic appearance, discomfort during suture removal and patient satisfaction. The possibility of blinding the investigator was null as the researcher and investigator were the same.

The data collected were entered into Microsoft excel spread sheet 2010 and statistical analysis were performed using statistical package for social sciences software (SPSS). Descriptive statistics was applied to find out the proportions and in order to find out the association between the variables Chi-square test was applied. When the $\mathrm{P}$-value was $<0.05$ the association was said to be statistically significant.

\section{Results}

Totally 100 study participants were recruited into the study. Wound closure was done with staples in 50 study participants and staples in 50 study participants. Both the groups were found to be similar in characteristics like age, sex and education with p-value of more than 0.05 (Table1).

The mean time for wound closure was lesser when staples were used compared to the sutures, $5.52 \pm 1.11$ mins and 9.92 \pm 2.37 mins, respectively. The above difference was found to be statistically significant. The duration of hospital stay was almost equal in both the groups (table2).

Wound infection was present in $36 \%$ of cases in the staples group and in $74 \%$ of cases in the suture group. The above difference was statistically significant with a p-value $<0.05$. Wound dehiscence occurred in $12 \%$ and $16 \%$ of the cases 
in staple and suture group, respectively. Though wound dehiscence occurred lesser in staples group, the difference was not statistically significant. Good cosmetic appearance was present in $82 \%$ of the staples group and $54 \%$ of the sutures group and the difference was found to be statistically significant (Table 3 ).

Discomfort in suture removal was present only in $6 \%$ of the cases when staples were used against
96\% when sutures were used. The above difference was found to be statistically significant. $88 \%$ of the patients were satisfied in staples group against $38 \%$ in the control group. The above difference was statistically significant indicating patient were more satisfied with staples than sutures.

Table 1: Distribution of Socio-demographic characteristics between the staples and sutures group

\begin{tabular}{|c|c|c|c|c|c|c|}
\hline \multirow{2}{*}{\multicolumn{2}{|c|}{ Variables }} & \multicolumn{2}{|c|}{ Staples } & \multicolumn{2}{|c|}{ sutures } & \multirow{2}{*}{ p-value } \\
\hline & & \multirow{2}{*}{$\frac{\mathbf{N}}{2}$} & \multirow{2}{*}{$\begin{array}{c}\% \\
100\end{array}$} & \multirow{2}{*}{$\frac{\mathbf{N}}{0}$} & \multirow{2}{*}{$\begin{array}{c}\% \\
0\end{array}$} & \\
\hline \multirow{7}{*}{ Age } & $<10$ & & & & & \multirow{7}{*}{$>0.05$} \\
\hline & $10-20$ & 5 & 62.5 & 3 & 37.5 & \\
\hline & $20-30$ & 4 & 50 & 4 & 50 & \\
\hline & $30-40$ & 11 & 55 & 9 & 45 & \\
\hline & $40-50$ & 5 & 25 & 15 & 75 & \\
\hline & $50-60$ & 7 & 38.9 & 11 & 61.1 & \\
\hline & $\geq 60$ & 16 & 66.7 & 8 & 33.3 & \\
\hline \multirow{2}{*}{ Sex } & Male & 35 & 49.3 & 36 & 50.7 & \multirow{2}{*}{$>0.05$} \\
\hline & Female & 15 & 51.7 & 14 & 48.3 & \\
\hline \multirow{6}{*}{ Education } & Illiterate & 11 & 50 & 11 & 50 & \multirow{6}{*}{$>0.05$} \\
\hline & Primary & 9 & 50 & 9 & 50 & \\
\hline & Secondary & 10 & 71.4 & 4 & 28.6 & \\
\hline & Higher secondary & 8 & 40.0 & 12 & 60.0 & \\
\hline & Undergraduate & 11 & 45.8 & 13 & 54,2 & \\
\hline & Postgraduate & 1 & 50 & 1 & 50 & \\
\hline \multicolumn{2}{|l|}{ Total } & 50 & 50 & 50 & 50 & \\
\hline
\end{tabular}

Table 2: Comparison of time of closure and duration of hospital stay between staples and sutures

\begin{tabular}{|l|c|c|c|c|c|}
\hline Variable & Group & Mean & SD & t-value & \multirow{2}{*}{ p-value } \\
\hline $\begin{array}{l}\text { Time of wound } \\
\text { closure }\end{array}$ & Staplers & $5.52^{*}$ & 1.11 & \multirow{2}{*}{11.81} & \multirow{2}{*}{$<0.05$} \\
\cline { 2 - 4 } & Sutures & $9.90^{*}$ & 2.37 & \\
\hline $\begin{array}{l}\text { Duration of } \\
\text { hospital stay }\end{array}$ & Staplers & $11.84^{\#}$ & 4.68 & \multirow{2}{*}{0.333} & $>0.05$ \\
\cline { 2 - 4 } & Sutures & $12.14^{\#}$ & 4.31 & \multirow{2}{*}{$>$} \\
\hline
\end{tabular}

*in minutes.

\#in days.

\&independent samples $\mathrm{t}$-test was applied.

Table 3: Comparison between the suture and staplers group with respect to wound infection, wound dehiscence, cosmetic appearance, discomfort during suture removal and patient satisfaction

\begin{tabular}{|c|c|c|c|c|c|}
\hline \multicolumn{2}{|l|}{ Variable } & Staples & Sutures & $\mathrm{X}^{2}$ - value & P-value \\
\hline \multirow{2}{*}{$\begin{array}{l}\text { Wound } \\
\text { infection }\end{array}$} & Present & $18(36.0)$ & $37(74.0)$ & \multirow{2}{*}{14.58} & \multirow{2}{*}{$<0.05^{*}$} \\
\hline & Absent & $32(64.0)$ & $13(26.0)$ & & \\
\hline \multirow{2}{*}{ Wound dehiscence } & Present & $6(12.0)$ & $8(16.0)$ & \multirow{2}{*}{0.332} & \multirow{2}{*}{$>0.05$} \\
\hline & Absent & $44(88.0)$ & $42(84.0)$ & & \\
\hline \multirow{2}{*}{ Cosmetic appearance } & Good & $41(82.0)$ & $27(54.0)$ & \multirow{2}{*}{9.007} & \multirow{2}{*}{$<0.05^{*}$} \\
\hline & Poor & $9(18.0)$ & $23(46.0)$ & & \\
\hline \multirow{2}{*}{$\begin{array}{lll}\text { Discomfort during } & \text { suture } \\
\text { removal } & & \\
\end{array}$} & Present & $3(6.0)$ & $48(96.0)$ & \multirow{2}{*}{81.03} & \multirow{2}{*}{$<0.05^{*}$} \\
\hline & Absent & $47(94.0)$ & $2(4.0)$ & & \\
\hline \multirow{2}{*}{ Patient satisfaction } & Good & $44(88.0)$ & $19(38.0)$ & \multirow{2}{*}{26.81} & \multirow{2}{*}{$<0.05^{*}$} \\
\hline & Poor & $6(12.0)$ & $31(62.0)$ & & \\
\hline
\end{tabular}

*statistically significant. 


\section{Discussion}

This was non-randomised controlled trial carried out in a tertiary care centre with objective to compare between staples and sutures in case of laparotomy surgeries. 50 patients were recruited into the experimental group and wound closure was done with staples and 50 patients acted as their controls where wound closure was done with sutures. Both the group were found to be similar in factors like age, sex and education.

The time for wound closure was significantly lesser in the staples group compared to the suture group. Similar results were obtained by Mackeen $\mathrm{AD}$ et $\mathrm{al}^{(8)}$, yuenyongviwat et $\mathrm{al}^{(7)}$ and Rohin $\mathrm{K}^{(9)}$. Staples were superior to sutures when time for closure was taken into account. Duration of hospital stay was found to be similar in both the groups by the present study. Similar results were obtained by Imamura et $\mathrm{al}^{(10)}$. Wang $\mathrm{H}$ also reported that there was no difference in the duration of hospital stay between sutures and staples group ${ }^{(11)}$.

Wound infection occurred more in the sutures group than the staples group in the present study. A study conducted by Oswal et al in the year 2017 also reported that those patients whose skin closure was done by sutures had increased chance of infection than those patients whose skin closure was done by staples ${ }^{(12)}$. Similar results were obtained by Batra $\mathrm{J}$ et al in which he reported that wound discharge were present in more proportion among those who received sutures $(10.5 \%)$ for closure than among those who received staples $(5.3 \%)^{(13)}$. Skin closure with the help of sutures caries more risk of wound infection than those by sutures, because a needle passing through the intact skin on either side of the wound carries both epidermis and organisms along its track and into the depths of the wound, thereby causing a higher incidence of wound infection than skin closure by a suture less technique ${ }^{(13)}$.

The present study found out that cosmetic appearance was better when staples was used compared to the sutures. A stapled wound has no 'cross- hatched' scarring because the tissue is able to expand under the 'open rectangle' formation of the staple com- pared with a simple interrupted suture, which applies tension at the healing skin edge $^{(7)}$.

The present study also reported that patient felt less discomfort when staples were removed than the stures. Similar results were obtained by Oswal et $\mathrm{al}^{(12)}$, Batra $\mathrm{J}$ et $\mathrm{al}^{(13)}$. Staples were usually removed with devices that painlessly opened them sideways $^{(6)}$.

The present study reported higher degree of patient satisfaction when staplers were used rather than the sutures. Yuenyongviwat et al reported that there was no difference in patient satisfaction score between sutures and staplers ${ }^{(7)}$. Similar results were reported by Wang $\mathrm{H}^{(11)}$. Since satisfaction is a subjective phenomenon the results in the present study could be due to the decrease in complications, better cosmesis, less discomfort during suture removal when staples were used.

Limitations: Absence of randomisation would have influenced the result of the study, less sample size, blinding was not done as patient would eventually see the type of biomaterial used for wound closure and since the investigator and interviewer were same it was not feasible.

\section{Conclusion}

Staples were superior to sutures with respect to time for closure of the wound, occurrence of lesser complications namely lesser wound infections, better cosmesis, less discomfort during suture removal. All the above led to a satisfied patient.

\section{Reference}

1. Soni A, Narula R, Kumar A, Parmar M, Sahore M, Chandel M. Comparing cyanoacrylate tissue adhesive and conventional subcuticular skin sutures for maxillofacial incisions - A prospective randomized trial considering closure time, wound morbidity, and cosmetic outcome. J Oral Maxillofac Surg [Internet]. 2013;71(12):2152.e1-2152.e8. Available 
from: http://dx.doi.org/ 10.1016/j. joms.2013.08.029

2. Chavan DR, B B M, Kadlewad S, S B. Study of Skin Staples and Conventional Sutures for Abdominal Clean Wound Skin Closure: a Randomized Control Trial. J Evol Med Dent Sci [Internet]. 2014;3(20):5626-36. Available from: http://www.jemds.com/data_pdf/2_deepak chavan 2.pdf

3. Nagaraj V, Rajkumar G, Ghosh A, Nanjappa M. Comparison between stainless steel staples and silk sutures for primary closure of skin in patients undergoing neck dissection: A comparative clinical study. Contemp Clin Dent [Internet]. 2015;6(5):51. Available from: http://www.contempclindent. org/ text.asp?2015/6/5/51/152938

4. Tajirian AL, Goldberg DJ. A review of sutures and other skin closure materials. J Cosmet Laser Ther [Internet]. 2010 Dec 10 [cited 2018 Sep 18];12(6):296-302. Available from: http://www.tandfonline. com/ doi/full/10.3109/ 14764172.2010. 538413

5. Chu C-C, Von Fraunhofer JA (Joseph A, Greisler HP. Wound closure biomaterials and devices [Internet]. CRC Press; 1997 [cited 2018 Sep 13]. 400 p. Available from: https://books.google.co.in/ books?

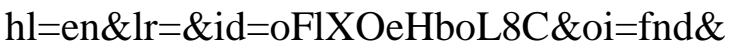
pg=PA $1 \& d q=$ wound+closure+history \&ots $=\mathrm{fVnp} 1 \mathrm{bU} 13 \mathrm{q} \& \mathrm{sig}=6 \mathrm{miyh} 5 \mathrm{qz} 4 \mathrm{y} 2 \mathrm{XWXzV}$ $\mathrm{y} 286$ fOPYOIA\# $\mathrm{v}=$ onepage $\& \mathrm{q}=$ wound closure history $\& \mathrm{f}=$ false

6. Gatt Frcs D, Hospital H. Staples for wound closure: a controlled trial [Internet]. Vol. 67, Annals oJ the Royal College of Surgeons of England. 1982 [cited 2018 Aug 13]. Available from: https://www.ncbi.nlm.nih.gov/pmc/articles /PMC2499561/pdf/annrcse01534-0048.pdf

7. Yuenyongviwat $\mathrm{V}$, Iamthanaporn $\mathrm{K}$, Hongnaparak T, Tangtrakulwanich B. A randomised controlled trial comparing skin closure in total knee arthroplasty in the same knee: nylon sutures versus skin staples. Bone Jt Res [Internet]. 2016;5(5):185-90. Available from: http://www.bjr.boneandjoint.org.uk/cgi/doi /10.1302/2046-3758.55.2000629

8. Mackeen AD, Schuster M, Berghella V. Suture versus staples for skin closure after cesarean: a metaanalysis. Am J Obstet Gynecol [Internet]. 2015 May [cited 2018 Aug 15];212(5):621.e1-621.e10. Available from: http://www.ncbi.nlm.nih.gov/ pubmed/25530592

9. Krishnan R, MacNeil SD, MalvankarMehta MS. Comparing sutures versus staples for skin closure after orthopaedic surgery: systematic review and metaanalysis. BMJ Open [Internet]. 2016 Jan 20 [cited 2018 Sep 18];6(1):e009257. Available from: http://bmjopen.bmj.com/ lookup/doi/10.1136/bmjopen-2015-009257

10. Imamura K, Adachi K, Sasaki R, Monma S, Shioiri S, Seyama Y, et al. Randomized Comparison of Subcuticular Sutures Versus Staples for Skin Closure After Open Abdominal Surgery: a Multicenter Open-Label Randomized Controlled Trial. J Gastrointest Surg [Internet]. 2016;20(12):2083-92. Available from: http://dx.doi.org/10.1007/s11605-0163283-z

11. Wang H, Hong S, Teng H, Qiao L, Yin H. Subcuticular sutures versus staples for skin closure after cesarean delivery: a metaanalysis. J Matern Neonatal Med. 2016;29(22):3705-11.

12. Oswal S, Borle R, Bhola N, Jadhav A, Surana S, Oswal R. Surgical Staples: A Superior Alternative to Sutures for Skin Closure After Neck Dissection-A SingleBlinded Prospective Randomized Clinical Study. J Oral Maxillofac Surg [Internet]. 2017;75(12):2707.e1-2707.e6. Available from: http://dx.doi.org/10.1016/ 
j.joms.2017.08.004

13. Batra J, Bekal RK, Byadgi S, Attresh G, Sambyal S, Vakade CD. Comparison of Skin Staples and Standard Sutures for Closing Incisions After Head and Neck Cancer Surgery: A Double-Blind, Randomized and Prospective Study. J Maxillofac Oral Surg [Internet]. 2016;15(2):243-50. Available from: http://link.springer.com/10.1007/s12663015-0809-y. 